\title{
Acute renal failure and lithium intoxication
}

\author{
S. LAVENDER \\ M.A., M.B., M.R.C.P.
}

\author{
J. N. BRowN \\ M.A., B.M., M.R.C.P.
}

\author{
W. T. BERRILL \\ M.B., B.S., M.R.C.P. \\ Wessex Regional Renal Unit, St Mary's Hospital, Portsmouth
}

\section{Summary}

A case of acute renal failure is reported in a patient with severe lithium intoxication. Renal biopsy showed damage in the proximal tubules with less marked changes in the glomeruli and interlobular arteries.

Lithium was withdrawn, and after treatment with peritoneal dialysis the patient regained normal renal function.

"* The accumulation of lithium is known to lead to acute renal failure in the rat and the $\mathrm{dog}$, and this report provides further evidence that it may do so in man.

THE features of lithium toxicity in man have been described by Schou, Amdisen \& Trap-Jensen (1968). They reported eight patients with severe intoxication, seven of whom developed mild impairment of renal function during coma. One case has been reported in which severe intoxication was associated with uraemia, which responded to fluid infusion (Verbov, Phillips \& Fife, 1965). Two cases of acute renal failure associated with lithium toxicity have been reported (Hawkins \& Dorken, 1969; Amdisen \& Skoldborg, 1969). In the first acute renal failure may have been related to hypotension, but in the second no cause was found.

Renal tubular damage and oliguric renal failure are known to occur as a direct result of lithium toxicity in experimental animals (Radomski et al., 1950; Schou, 1958). This report provides further evidence that this may also occur in man.

\section{Case report}

A 59-year-old woman was referred to the Wessex Regional Renal Unit after what was thought to be an overdose of lithium. In the past she had suffered from repeated episodes of mania and depression. These had been controlled for 2 years by treatment with lithium. Serum lithium had not been estimated but before treatment blood urea was $28 \mathrm{mg} / 100 \mathrm{ml}$ and there was no proteinuria. She received slowrelease lithium carbonate tablets $400 \mathrm{mg}$ daily at first, increased to $800 \mathrm{mg}$ daily for the last 3 months.
The tablets had been in the custody of her brother, who supervised their administration and was able to account for the correct number of unused tablets at the time of admission.

A week previously she had noticed transient diarrhoea. For 3 days she suffered from anorexia, drowsiness and involuntary movements. She had been oliguric for at least $24 \mathrm{hr}$.

On admission she was conscious; there was dysarthria associated with rigidity of the jaw. She had choreiform involuntary movements, a coarse tremor and cogwheel rigidity involving all limbs. Pulse rate was $70 / \mathrm{min}, \mathrm{BP} 110 / 70 \mathrm{mmHg}$ lying and $90 / 60 \mathrm{mmHg}$ sitting. CVP $+10 \mathrm{~cm}$. There was no oedema. The heart, lungs and abdomen were clinically normal. Urine testing showed a trace of protein and on microscopy there were no casts.

Investigations. Serum lithium $5.2 \mathrm{mEq} / \mathrm{l}$, serum urea $110 \mathrm{mg} / 100 \mathrm{ml}$, sodium $130 \mathrm{mEq} / \mathrm{l}$, potassium $5.0 \mathrm{mEq} / \mathrm{l}$, bicarbonate $29 \mathrm{mEq} / \mathrm{l}$, urine urea 150 $\mathrm{mg} / 100 \mathrm{ml}$, sodium $17 \mathrm{mEq} / \mathrm{l}$ and osmolality 317 $\mathrm{mmol} / \mathrm{kg}$. Hb $9.6 \mathrm{~g} / 100 \mathrm{ml}$; blood film showed irregularly contracted red cells with fragmented and burr forms. Serum bilirubin $2 \cdot 8 \mathrm{mg} / 100 \mathrm{ml}$, albumen $3.0 \mathrm{~g} / 100 \mathrm{ml}$, globulin $2.9 \mathrm{~g} / 100 \mathrm{ml}$, SGOT $76 \mathrm{IU} / \mathrm{ml}$, and alkaline phosphatase $10 \mathrm{KA}$ units $/ 100 \mathrm{ml}$. Prothrombin time, fibrinogen titre and serum haptoglobin normal and Schumm's test for methaemalbumin negative. Antistreptolysin titre less than 50 units/ ml. Nephrotomograms showed normal sized kidneys.

A diagnosis was made of acute renal failure associated with lithium toxicity. Peritoneal dialysis was started for the removal of lithium (Wilson et al., 1971) and the control of uraemia. Serum lithium fell to $1.9 \mathrm{mEq} / 1$ after $24 \mathrm{hr}$ and to $0.9 \mathrm{mEq} / 1$ after $48 \mathrm{hr}$. She remained anuric and severely ill for 7 days but then passed increasing volumes of urine. Peritoneal dialysis was discontinued and her clinical condition steadily improved. Haemoglobin after 1 week fell to $5.7 \mathrm{~g} / 100 \mathrm{ml}$ and she was transfused 2 pints of blood. Her blood urea fell spontaneously to $32 \mathrm{mg} / 100 \mathrm{ml}$ with serum creatinine $1 \mathrm{mg} / 100 \mathrm{ml}$ and creatinine clearance $77 \mathrm{ml} / \mathrm{min}$. There was no proteinuria and 
an IVP was normal. Liver function tests returned to normal. Barium enema and sigmoidoscopy were normal, barium meal showed gastro-oesophageal reflux but was otherwise normal. After treatment with oral iron, haemoglobin returned to normal.

A renal biopsy was taken 2 weeks after admission (Fig. 1). Out of fifteen glomeruli in the biopsy one was

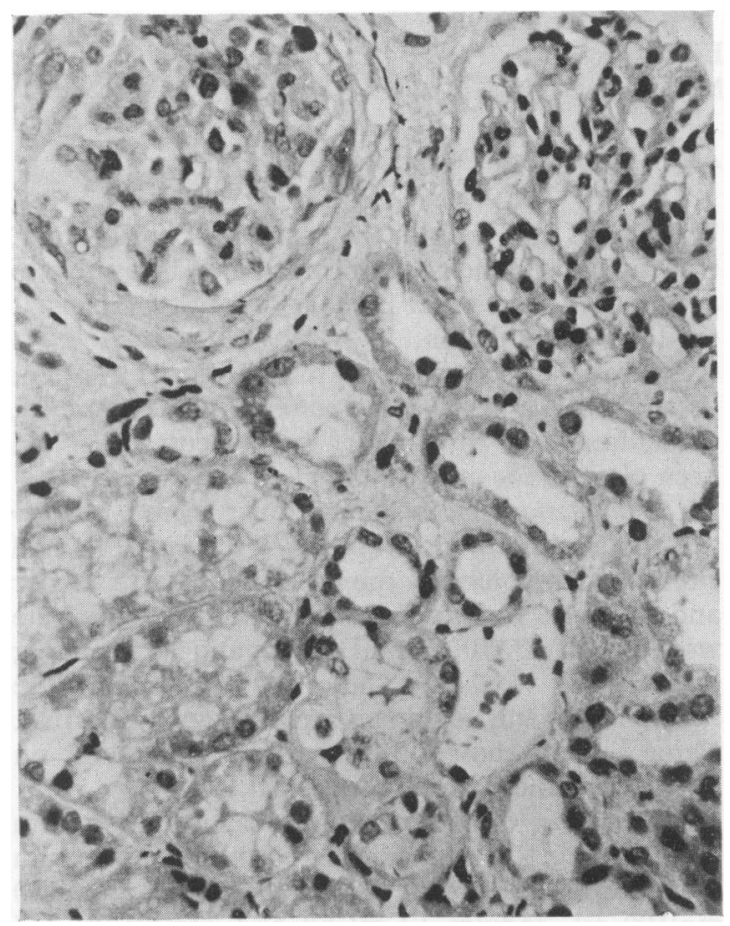

FIg. 1. Photomicrograph from renal biopsy. Glomeruli show some mesangial thickening with corresponding cellular proliferation. There is prominent cytoplasmic vacuolation in some proximal tubules and many tubular epithelial cells have pyknotic nuclei. H \& E, X 196.

completely sclerosed. There was slight proliferation of visceral and parietal epithelial cells in a few of the glomeruli with focal mesangial thickening and an occasional capsular adhesion. Tubular changes were more marked with loss of differentiation of epithelial cells lining many dilated convoluted tubules. Also striking was the presence of hyaline droplets in, and vacuolation of, proximal epithelial cell cytoplasm. Many tubular cell nuclei were pyknotic. Interlobular arteries showed moderate intimal fibrosis and reduplication of internal elastic lamina. Electron microscopy confirmed the disproportion of tubular to glomerular damage.

\section{Discussion}

There is doubt as to the exact sequence of events leading to the development of acute renal failure in this patient. However, a direct nephrotoxic effect of lithium remains the most likely cause. The lithium dose had been doubled 3 months previously. An assessment of her dietary sodium intake showed it to have been about $170 \mathrm{mEq} /$ day. During the week prior to admission she ate very little; this may have been due to prodromal symptoms of lithium toxicity. The consequent reduced sodium intake would have led to further accumulation of lithium (Thomsen \& Schou, 1968). There was no evidence to suggest that she was suffering from uncorrected prerenal uraemia.

The renal biopsy showed minor glomerular changes which might be attributed to vascular sclerosis. Schou et al. (1968) demonstrated marked renal vascular sclerosis in the two cases of lithium poisoning where histology was obtained. It is possible that some pre-existing glomerular disease could have contributed to the accumulation of lithium, although the recovery of normal renal function on withdrawing lithium makes this unlikely to have been a major factor. The two previously reported cases of acute renal failure in lithium poisoning (Hawkins \& Dorken, 1969; Amdisen \& Skjoldborg, 1969) do not include renal histology. The finding of transient proteinuria on starting lithium treatment (Glesinger, 1954) and in lithium toxicity (Schou et al., 1968; Roberts, 1950) would be in keeping with glomerular damage.

In studies of lithium intoxication in rats Schou (1958) showed the main toxic effect to be on the kidneys. Early poisoning was associated with failure of urinary concentration and minor histological changes in the proximal tubules. With increasing doses of lithium rats died of oliguric renal failure. There were gross histological changes in the proximal tubules. Radomski et al. (1950) described similar findings in the dog although the main histological abnormalities were in the distal tubules. Lithium was not found to produce glomerular damage in either the rat or dog.

Peritoneal dialysis and haemodialysis have been advocated for the treatment of lithium intoxication (Hawkins \& Dorken, 1969; Amdisen \& Skjoldborg, 1969; Wilson et al., 1971). In our case lithium removal in the dialysate was relatively slow, only approximately $30 \mathrm{mEq}$ being removed in the first $24 \mathrm{hr}$. Thereafter dialysate lithium levels were too low to determine accurately but serum levels continued to fall exponentially without the passage of urine. The anaemia may have been secondary to acute renal failure, although there was no evidence of extensive haemolysis. There was no overt gastro-intestinal haemorrhage but previous dietary deficiency of iron and blood loss from the hiatus hernia are possible contributory causes.

As lithium is now widely being used for prophylaxis in affective disorders there is a risk of an 
increasing incidence of lithium poisoning. It can be prevented by preliminary assessment of renal function and monitoring of the serum lithium especially if there is any change in the patient's condition. As renal excretion is the only route of elimination of lithium, acute renal failure is a serious complication of an already hazardous condition.

\section{Acknowledgments}

We thank Professor A. Polak for his advice, Dr J. Burston for the histological report and the nurses of the Wessex Regional Renal Unit for their skilled attention.

\section{References}

Amdisen, A. \& Skoldborg, H. (1969) Haemodialysis for lithium poisoning. Lancet, ii, 213.
GLesinger, B. (1954) Evaluation of lithium in treatment of psychotic excitement . Medical Journal of Australia, 41, 277.

Hawkins, J.B. \& Dorken, P.R. (1969) Lithium. Lancet, i, 839.

Radomski, J.L., Fuyat, H.N., Nelson, A.A. \& Smith, P.K. (1950) Toxic effects, excretion and distribution of lithium chloride. Journal of Pharmacology, 100, 429.

RoBERTS, E.L. (1950) A case of chronic mania treated with lithium citrate and terminating fatally. Medical Journal of Australia, 37, 261.

Schou, M. (1958) Lithium studies. I. Toxicity. Acta pharmacologica et toxicologica, 15, 70.

Schou, M., Amdisen, A. \& Trap-Jensen, J. (1968) Lithium poisoning. American Journal of Psychiatry, 125, 520.

ThOMSEN, K. \& Schou, M. (1968) Renal lithium excretion in man. American Journal of Physiology, 215, 823.

Verbov, J.L., Phillips, J.D. \& Fife, D.G. (1965) Case of lithium intoxication. Postgraduate Medical Journal, 41, 190.

WILsON, J.H.P., DONKer, A.J.M., VAN DER HeM, G.K. \& WiENKJES, J. (1971) Peritoneal dialysis for lithium poisoning. British Medical Journal, 2, 749.

\title{
Haemolytic anaemia in myelomatosis
}

\author{
C. D. R. Pengelly \\ M.D., F.R.C.P., F.R.C.P.E.
}

\author{
B. K. MONDAL \\ M.B., B.S., D.T.M. \& H.
}

\author{
A. R. BARUA \\ M.B., B.S., D.T.M. \& H. \\ The Grange Hospital, Weaverham, Cheshire
}

\begin{abstract}
Summary
A case of IgA myelomatosis with a haemolytic anaemia is described. No auto-antibodies could be found and the mechanism of the haemolysis was obscure.

Haemolytic anaemia is a rare complication but a search of the literature has revealed a few cases with a comparable shortening of red cell life-span, most without auto-antibodies but some with a positive Coombs' test.
\end{abstract}

\section{Introduction}

Myelomatosis is not a rare disease. Anaemia, leucopenia and thrombocytopenia are common complications, the cause usually being accepted as due to bone-marrow invasion with the abnormal plasma cells. Haemolytic anaemia has been described, but commonly amounts to no more than a mild to moderate degree of shortening of the red cell lifespan. Twelve such cases are described by Cline \& Berlin (1962) with a minimum half-chromium time $\left(\mathrm{T}_{\frac{1}{2}}{ }^{151} \mathrm{Cr}\right)$ of 16 days all with negative Coombs' tests and another by Bowdler \& Prankerd (1962) with a red cell life-span of 15 days. These patients showed no evidence of the presence of auto-antibodies, but Pirofsky (1969) discusses nine patients with autoimmune haemolytic anaemia and myelomatosis and Dacie (1967) refers to seven patients in the literature with myelomatosis and positive Coombs' tests.

We report here a patient with IgA myelomatosis, overt clinical and laboratory evidence of haemolysis, a red cell life-span of about 30 days and an absence of demonstrable auto-antibodies.

\section{Case report}

Mr William D., aged 79 , a retired wireman, previously healthy, was admitted to a local cottage hospital on 15 January 1971 with bilateral bronchopneumonia. This was treated with ampicillin but was slow in resolving and the patient was referred to a chest physician (Dr M. Pemberton) who found anaemia (Hb 7.0 g/100 ml) and a very high ESR (71 $\mathrm{mm} / \mathrm{hr}$ Wintrobe). Plasma proteins showed a high globulin level and immunoelectrophoresis a very high IgA level and sternal marrow examination 